\title{
Isolation of Plasmid DNA Sequences That Complement Rhodobacter sphaeroides Mutants Deficient in the Capacity for $\mathrm{CO}_{2}$-dependent Growth
}

\author{
By A. MELINDA RAINEY AND F. ROBERT TABITA* $\dagger$ \\ Center for Applied Microbiology and Department of Microbiology, The University of Texas \\ at Austin, Austin, TX 78712-1095, USA
}

(Received 13 October 1988; revised 27 January 1989; accepted 20 February 1989)

\begin{abstract}
Mutants deficient in the proper regulation and derepression of ribulose-1,5-bisphosphate carboxylase/oxygenase (RuBPC/O) in Rhodobacter sphaeroides were isolated by ethyl methanesulphonate (EMS) and Tn5 mutagenesis of a $r e c A$ parental strain. Mutants were identified by their ability to grow under conditions where the organism requires basal levels of $\mathrm{RuBPC} / \mathrm{O}$ for growth yet fail to grow under conditions which require derepression of the enzyme $\left(\right.$ Aut $\left.^{-}\right)$. The newly isolated Aut ${ }^{-}$mutants exhibited phenotypes distinguishable from the previously isolated $\mathrm{Aut}^{-}$mutant, strain $\mathrm{KW} 25 / 11$. Rocket immunoelectrophoretic examination of $\mathrm{RuBPC} / \mathrm{O}$ levels revealed marked variance in the ability of mutants to derepress form I and form II RuBPC/O in the absence of exogenous carbon. Evidence that some of the mutants possessed different mutations was substantiated by complementation of the EMS-generated mutants by entirely different genes isolated from a genomic library of $R$. sphaeroides constructed in the broad-host-range cosmid vector pVK102. Southern hybridization analysis of the complementing library isolates showed the complementing genes to be normally carried on the endogenous plasmids of $R$. sphaeroides. The gene complementing mutant strain KW25/11 was mapped by $\mathrm{Tn} 5$ insertional inactivation and the complementing region found to reside on a $1.5 \mathrm{~kb}$ Pst I-BamHI fragment. Complemented strains were unable to match wild-type levels of $\mathrm{RuBPC} / \mathrm{O}$ under conditions requiring derepression of the enzyme, except for mutant strain EMS45. The Aut ${ }^{-}$phenotype, represented by the mutants isolated in this study, stems from a deficiency in some aspect of photoautotrophic growth.
\end{abstract}

\section{INTRODUCTION}

The assimilation of carbon dioxide through the reductive pentose phosphate cycle (Calvin cycle) of photosynthesis is the source of nearly all organic matter consumed by biological systems. All plants and most autotrophic bacteria initiate carbon dioxide fixation by the action of the bifunctional enzyme, ribulose-1,5-biphosphate carboxylase/oxygenase (RuBPC/O) (Miziorko \& Lorimer, 1983; Tabita, 1988). Several members of the Rhodospirillaceae, Rhodobacter sphaeroides, Rhodobacter capsulatus, Rhodopseudomonas blastica, and Rhodopseudomonas palustris, possess two distinct forms of the enzyme: an L8S8 plant-type enzyme (form I) and an enzyme containing large subunits only (form II) (Gibson \& Tabita, 1977 a, c; Shively et al., 1984; Dow, 1987; Tabita, 1988). The two forms are immunologically distinct (Gibson \& Tabita, $1977 b$ ) and, at least in Rhodobacter sphaeroides, the products of different genes (Quivey \& Tabita, 1984; Muller et al., 1985; Gibson \& Tabita, 1986).

$\dagger$ Present address: Department of Microbiology, The Ohio State University, 484 W. 12th Avenue, Columbus, Ohio 43210, USA.

Abbreviations: RuBPC/O, ribulose 1,5-bisphosphate carboxylase/oxygenase; PRK, phosphoribulokinase; EMS, ethyl methanesulphonate. 
Conspicuously absent, however, from extensive information available on the biochemistry and physiology of procaryotic RuBPC/O (Tabita, 1988), is knowledge of genes directly, or indirectly, involved in the molecular regulation of $\mathrm{CO}_{2}$ fixation and $\mathrm{RuBPC} / \mathrm{O}$ synthesis. Due to its exceptional metabolic versatility, Rhodobacter sphaeroides is an excellent organism in which to study regulation. When this bacterium is grown photolithoautotrophically in an atmosphere of $\mathrm{H}_{2}$ and low levels of $\mathrm{CO}_{2}$, or photoheterotrophically in a butyrate/bicarbonate medium, the synthesis of both phosphoribulokinase (PRK) and RuBPC/O is derepressed. Although synthesis of both forms of $\mathrm{RuBPC} / \mathrm{O}$ is significant under these conditions, the form I enzyme predominates, strongly suggesting that there is separate control of the synthesis of the two RuBPC/O enzymes (Jouanneau \& Tabita, 1986). By contast, photoheterotrophic growth with oxidized sources of carbon, such as malic acid, results in the synthesis of only low basal levels of PRK and RuBPC/O (Tabita, 1981). Therefore, strains able to maintain good photoheterotrophic growth on malate but unable to grow photolithoautotrophically or photoheterotrophically with butyrate as the electron donor would fit the classic phenotype of regulatory mutants $\left(\right.$ Aut $^{-}$) (Weaver \& Tabita, 1983). Studies on Aut ${ }^{-}$mutants in Alcaligenes eutrophus have demonstrated the importance of plasmid DNA in the regulation of RuBPC/O (Andersen \& Wilke-Douglas, 1984; Bowien et al., 1984). In this organism, plasmid-cured strains were incapable of $\mathrm{CO}_{2}$-dependent growth, but grew when supplied with formate as the carbon and energy source. This indicated that although plasmid-encoded functions were not essential for autotrophic carbon fixation, the plasmid-less strains displayed only partial derepression of RuBPC/O (Bowien et al., 1984). In another investigation, complementation studies indicated that the phenotype of $A$. eutrophus Aut ${ }^{-}$mutant AE370 was due to production of an inactive RuBPC/O (Andersen \& Wilke-Douglas, 1987).

Rhodobacter sphaeroides is amenable to genetic studies employing the broad-host-range $\mathbf{R}$ plasmids and their derivatives (Andersen \& Valentine, 1982). Genes involved in the regulation of carbon fixation in $R$. sphaeroides have already been isolated from a $R$. sphaeroides strain HR DNA library constructed in the cosmid vector pVK102 (Weaver \& Tabita, 1985). Clones containing the structural genes for both forms of $\mathrm{RuBPC} / \mathrm{O}$ were identified from this library by the use of heterologous DNA probes (Gibson \& Tabita, 1986). Also located on the same library fragments are the structural genes for two distinct forms of PRK, and fructose-1,6bisphosphatase, as well as a single glyceraldehyde-3-phosphate dehydrogenase gene (Gibson \& Tabita, 1987, 1988). Immediately upstream of both the form I and form II RuBPC/O genes are two homologous sequences, $c f x A$ and $c f x B$, respectively (Gibson \& Tabita, 1988), that encode proteins of $M_{\mathrm{r}}$ about 37000 (Hallenbeck \& Kaplan, 1987) that appear to affect the expression of the form I and form II RuBPC/O genes (J. L. Gibson \& F. R. Tabita, unpublished results). In the present study, mutagenesis and complementation procedures have been used to isolate and identify genes involved in the regulation of $\mathrm{CO}_{2}$ fixation in $R$. sphaeroides.

\section{METHODS}

Reagents. All biochemicals were purchased from Sigma. All compounds were of reagent grade quality; $\mathrm{NaH}^{14} \mathrm{CO}_{3}\left(20 \mathrm{mCi} \mathrm{mmol}^{-1} ; 740 \mathrm{MBq} \mathrm{mmol}^{-1}\right)$ was purchased from Amersham.

Bacterial strains and plasmids. All bacterial strains and plasmids used in this study are listed in Table 1. Rhodobacter sphaeroides strain WS129 is a rec-1, lys- 1 mutant (Sistrom et al., 1984) of strain WS22 (lys- 1 ) which, in turn, was derived from the wild-type isolate strain WS8 (Sistrom, 1977). These strains are reported to contain two endogenous plasmids, pRSWSa (130 kb) and pRSWSb (100 kb) (Fornari et al., 1984). R. sphaeroides strain HR is a streptomycin-resistant $\left(\mathrm{Sm}^{\mathrm{R}}\right)$, heat-resistant spontaneous mutant of strain NCIB 8253 (Weaver \& Tabita, 1985) and is reported to contain only one endogenous plasmid, pRS8253a (106.5 kb) (Fornari et al., 1984).

Media and growth conditions. $R$. sphaeroides strains were grown photoheterotrophically on vitaminsupplemented PYE medium $[0.3 \%$ peptone, $0.3 \%$ yeast extract, $10 \%$ (v/v) Ormerod's basal salts (Ormerod et al., 1961)] or defined media containing malate or butyrate with sodium bicarbonate as previously described (Weaver \& Tabita, 1983). L-Lysine $\left(40 \mu \mathrm{g} \mathrm{ml}^{-1}\right)$ was added to the medium for all strains derived from strain WS129. Photolithoautotrophic growth in a minimal salts medium (MSM) under an atmosphere of $1.5 \%(\mathrm{v} / \mathrm{v}) \mathrm{CO}_{2}$ in $\mathrm{H}_{2}$ followed previously published procedures (Weaver \& Tabita, 1983).

Conjugation of plasmid-containing Escherichia coli strains with recipient $R$. sphaeroides cells was performed as previously described (Weaver \& Tabita, 1985). 
Table 1. Bacterial strains and plasmids

\begin{tabular}{|c|c|}
\hline Bacterial strains & Relevant genotype or phenotype \\
\hline \multicolumn{2}{|c|}{ Rhodobacter sphaeroides } \\
\hline WS22 & lys -1 \\
\hline WS 129 & rec-1 lys-1 \\
\hline HR & $\mathrm{Sm}^{\mathrm{R}}$, heat resistant \\
\hline EMS45 & rec-1 lys-1, Aut ${ }^{-}$ \\
\hline EMS47 & rec-1 lys-1, Aut $^{-}$ \\
\hline KW25/11 & $\mathrm{Sm}^{\mathrm{R}} \mathrm{Km}^{\mathrm{R}}$, heat resistant $(\mathrm{pJB} 4 \mathrm{JI})$ \\
\hline HR5 & $\mathrm{Sm}^{\mathrm{R}} \mathrm{Km}^{\mathrm{R}}$, heat resistant $(\mathrm{Tn} 5, \mathrm{R} 751)$ \\
\hline \multicolumn{2}{|l|}{ Escherichia coli } \\
\hline HB101 & $\begin{array}{l}\text { hsd } 20 \text { recA13 ara-14 proA2 lacY1 galK2 rpsL20 } \\
\left(\mathrm{Sm}^{\mathrm{R}}\right) \text { xyl-5 mtl-1 supE44 }\end{array}$ \\
\hline RM1058 & hsdM hsdR Nal ${ }^{\mathrm{R}}$ Rif $^{\mathrm{R}}$ lac4 supF44 \\
\hline $\mathrm{JM} 107$ & $\begin{array}{l}\text { endAl gyrA96 thi hsdR17 supE44 relA1 } \lambda^{-} \\
\Delta(\text { lac-proAB })\left[\mathrm{F}^{\prime} \text { traD36 pro } A B, \text { lac } I^{\mathrm{q}} \mathrm{Z} \Delta \mathrm{M} 15\right]\end{array}$ \\
\hline RM1628 & Identical to RM1058, Tn5 (chromosomal Tn5) \\
\hline \multicolumn{2}{|r|}{ be } \\
\hline pVK 102 & $\mathrm{Tc}^{\mathrm{R}} \mathrm{Km}^{\mathrm{R}}, \lambda \cos$ \\
\hline pUC8 & $\mathrm{Ap}^{\mathrm{R}}$ lacZ, Em15 \\
\hline pRK404 & $\mathrm{Tc}^{\mathrm{R}}, \operatorname{lac} Z, \mathrm{Em} 15$ \\
\hline pRK2013 & $\mathrm{Km}^{\mathrm{R}}, \mathrm{RK} 2-\mathrm{ColEt}_{\mathrm{rep}}, \mathrm{Tra}^{+}$ \\
\hline pJG336 & $\begin{array}{l}\mathrm{Tc}^{\mathrm{R}}, \mathrm{pVK} 102 \text { containing } \sim 20 \mathrm{~kb} \text {. sphaeroides } \\
\mathrm{DNA}, \text { form } \mathrm{I} \mathrm{CO}_{2} \text { fixation genes }\end{array}$ \\
\hline pJG106 & $\begin{array}{l}\mathrm{Tc}^{\mathrm{R}}, \mathrm{pVK} 102 \text { containing } 20 \mathrm{~kb} R \text {. sphaeroides } \\
\mathrm{DNA} \text {, form II } \mathrm{CO}_{2} \text { fixation genes }\end{array}$ \\
\hline pKWA200 & $\begin{array}{l}\mathrm{Tc}^{\mathrm{R}}, \text { pVK } 102 \text { containing } \sim 30 \mathrm{~kb} R \text {. sphaeroides } \\
\text { DNA, complement }{ }^{+} \mathrm{KW} 25 / 11\end{array}$ \\
\hline pMRA100 & $\begin{array}{l}\text { Tc }{ }^{\mathrm{R}}, \text { pVK } 102 \text { containing } \sim 21 \mathrm{~kb} R \text {. sphaeroides } \\
\text { DNA, complement }{ }^{+} \text {EMS } 45\end{array}$ \\
\hline pMRB500 & $\begin{array}{l}\mathrm{Tc}^{\mathrm{R}}, \mathrm{pVK} 102 \text { containing } \sim 18 \mathrm{~kb} R \text {. sphaeroides } \\
\text { DNA, complement }{ }^{+} \text {EMS } 47\end{array}$ \\
\hline pKW 1000 & $\begin{array}{l}3.2 \mathrm{~kb} R . \text { sphaeroides DNA Pst I fragment in } \\
\text { pUC8, Ap }{ }^{\mathrm{R}} \text {, complement }{ }^{+}\end{array}$ \\
\hline pWR4000 & $\begin{array}{l}3.2 \mathrm{~kb} R \text {. sphaeroides DNA Pst I cassette from } \\
\text { pKW } 1000 \text { in pRK } 404, \mathrm{Tc}^{\mathrm{R}} \text {, complement }{ }^{+}\end{array}$ \\
\hline pMR4502 & $\begin{array}{l}3 \cdot 2 \mathrm{~kb} R \text {. sphaeroides DNA in pRK } 404 \\
\text { inactivated with } \mathrm{Tn} 5, \mathrm{Tc}^{\mathrm{R}} \mathrm{Km}^{\mathrm{R}} \text {, complement }\end{array}$ \\
\hline pMR4503 & $\begin{array}{l}3.2 \mathrm{~kb} R \text {. sphaeroides DNA in pRK } 404 \\
\text { inactivated with } \mathrm{Tn} 5, \mathrm{Tc}^{\mathrm{R}} \mathrm{Km}^{\mathrm{R}} \text {, complement }\end{array}$ \\
\hline pMR4512 & $\begin{array}{l}3.2 \mathrm{~kb} R \text {. sphaeroides DNA in pRK } 404 \\
\text { inactivated with } \mathrm{Tn} 5, \mathrm{Tc}^{\mathrm{R}} \mathrm{Km}^{\mathrm{R}} \text {, complement }{ }^{+}\end{array}$ \\
\hline LibA & $\begin{array}{l}\mathrm{Tc}^{\mathrm{R}} \text {, pool of } 200 \text { transconjugants from } \\
R . \text { sphaeroides DNA library in pVK } 102\end{array}$ \\
\hline LibB & $\begin{array}{l}\mathrm{Tc}^{\mathrm{R}} \text {, pool of } 96 \text { transconjugants from } \\
R \text {. sphaeroides DNA library in pVK } 102\end{array}$ \\
\hline LibD & $\begin{array}{l}\mathrm{Tc}^{\mathrm{R}} \text {, pool of } 96 \text { transconjugants from } \\
R \text {. sphaeroides DNA library in pVK } 102\end{array}$ \\
\hline
\end{tabular}

\author{
Sistrom (1977) \\ Sistrom et al. (1984) \\ Weaver \& Tabita (1983) \\ This study \\ This study \\ Weaver \& Tabita (1985) \\ This study
}

Boyer \& Roulland-Sussaiz (1969)

R. Meyer, unpublished

Yanish-Perron et al. (1985)

R. Meyer, unpublished

Knauf \& Nester (1982)

Vieira \& Messing (1982)

Ditta et al. (1985)

Figurski \& Helinski (1979)

Gibson \& Tabita (1986, 1987, 1988)

Gibson \& Tabita (1986, 1987, 1988)

Weaver \& Tabita (1985)

This study

This study

Weaver (1985)

This study

This study

This study

This study

Weaver \& Tabita (1985)

This study

This study

Ethyl methanesulphonate mutagenesis. Dilutions of ethyl methanesulphonate (EMS) (Sigma) were prepared in $1.0 \mathrm{M}$-phosphate buffer ( $\mathrm{pH} \mathrm{7.4).} \mathrm{A} \mathrm{portion} \mathrm{of} \mathrm{a} \mathrm{stationary-phase} \mathrm{photoheterotrophic} \mathrm{culture} \mathrm{of} \mathrm{strain} \mathrm{WS129}$ $(1.0 \mathrm{ml})$ was added to each dilution and shaken at $37^{\circ} \mathrm{C}$ for $2 \mathrm{~h}$ to allow for the separation of mutant alleles from the wild-type. The cells were then washed twice in $0 \cdot 1 \mathrm{M}$-phosphate buffer ( $\mathrm{pH} 7 \cdot 4)$, resuspended in PYE $(1: 10)$ and shaken at $30^{\circ} \mathrm{C}$ for $48 \mathrm{~h}$. After this time, samples of each were plated and the dilutions scored for percentage survivors of original viable colony count. The $0.5 \mathrm{M}$ dilution was found to result in a $7 \%$ survival rate and was used for all subsequent EMS mutagenesis.

Four separate EMS mutagenesis attempts were accomplished as outlined above, except after aerobic growth in liquid culture, the cells were washed twice in MSM, resuspended in $30 \mathrm{ml} \mathrm{MSM}$ and bubbled with $1.5 \% \mathrm{CO}_{2}$ in $\mathrm{H}_{2}$ for $24 \mathrm{~h}$ to exhaust intracellular pools. Carbenicillin $(\mathrm{Cb})$ was then added to a final concentration of $200 \mu \mathrm{g} \mathrm{ml}-1$ and the cultures incubated for an additional $18 \mathrm{~h}$. The cultures were then harvested, washed and resuspended in fresh MSM $/ \mathrm{Cb}$ and subjected to an additional carbenicillin selection. Following a third cycle of carbenicillin 
selection, $0 \cdot 1 \mathrm{ml}$ volumes were plated onto malate plates and incubated aerobically. The resulting colonies were gridded onto fresh malate, MSM, and butyrate plates and grown under photosynthetic conditions for 7-10 d. Autotrophic mutants were selected for the capacity for good photosynthetic growth on malate plates and the concomitant inability to grow on both butyrate/bicarbonate or MSM plates. This selection procedure obviated the potential problem of isolating hydrogenase-negative strains with otherwise normal $\mathrm{CO}_{2}$ fixation capacity.

Derepression in carbon-free media. A photoheterotrophic malate-grown culture $(20 \mathrm{ml})$ was used to inoculate $500 \mathrm{ml}$ of fresh malate medium in a 1 litre vessel. Cultures were bubbled with argon until late exponential phase, the optical density at $650 \mathrm{~nm}$ measured, and then harvested. Half of each culture $(250 \mathrm{ml})$ was washed once in $50 \mathrm{mM}$-MOPS, pH 7.2, $10 \mathrm{mM}$-EDTA and the cell pellet frozen at $-20^{\circ} \mathrm{C}$. The remaining $250 \mathrm{ml}$ of culture was washed twice in MSM, resuspended in $500 \mathrm{ml} \mathrm{MSM}$, returned to a $30^{\circ} \mathrm{C}$ waterbath and bubbled with argon for an additional $3 \mathrm{~d}$. The resulting carbon-starved culture was then harvested and treated as above. The carboxylase activity in the malate-grown and the carbon-starved cells was determined by the whole-cell carboxylase assay (Tabita et al., 1978).

Derepression under photolithoautotrophic conditions. Either aerobically grown PYE cultures or anaerobically grown malate cultures $(10 \mathrm{ml})$ were washed twice in MSM and resuspended in $800 \mathrm{ml} \mathrm{MSM}$ medium. Cultures were incubated with an atmosphere of $1.5 \% \mathrm{CO}_{2}$ in $\mathrm{H}_{2}$. Zero time and daily samples were taken, prepared, stored, and assayed as above.

Preparation of cell extracts. Frozen cells were thawed and resuspended in about $1 \mathrm{ml} 50 \mathrm{~mm}-\mathrm{Tris}_{-} \mathrm{SO}_{4}, \mathrm{pH} 7 \cdot 2$, containing $10 \mathrm{mM}$-EDTA. Lysozyme was added to $0.125 \mathrm{mg} \mathrm{ml}^{-1}$ (final concentration) and the cells sonicated to achieve complete cell lysis. Chromatophores were removed by the addition of $50 \mathrm{~mm}-\mathrm{MgCl}_{2}$ followed by incubation at $50^{\circ} \mathrm{C}$ for $10 \mathrm{~min}$ (Jouanneau \& Tabita, 1986). After centrifugation at $15000 \mathrm{~g}$, the supernatant was removed and used for all subsequent assays. Protein concentration was determined by a modification of the Lowry protein assay (Markwell et al., 1978). Carboxylase activity was measured by the carboxylase assay previously described (Whitman \& Tabita, 1976).

Rocket immunoelectrophoresis. The concentration of form I and form II RuBPC/O in the cell extracts was quantified by rocket immunoelectrophoresis using antibodies specific for both enzymes (Jouanneau \& Tabita, 1986).

Complementation of autotrophic mutants. Mutants generated by EMS mutagenesis were complemented to an $R$. sphaeroides gene bank previously constructed (Weaver \& Tabita, 1985) in E. coli HB101. The gene bank is comprised of HindIII partial digests of $R$. sphaeroides strain HR DNA ligated into the broad-host-range cosmid vector pVK 102 encoding tetracycline resistance. The first 200 transconjugants were grown individually in microtitre plates containing $300 \mu \mathrm{l}$ per well of TYE/Tc (TYE is $0 \cdot 3 \%$ tryptone, $0 \cdot 3 \%$ yeast extract); $20 \mu \mathrm{l}$ was taken from each well, pooled and conjugated to $1.0 \mathrm{ml}$ of photoheterotrophically grown cultures of the individual mutants by the filter pad mating procedure [using pRK2013 as the mobilizing plasmid (Marrs, 1981)]. This pool was designated LiBA. The next 96 transconjugants in the gene bank were also grown individually in a microtitre plate, pooled and mated to the mutants as above. This second pool was designated LibB. Two additional pools, LibC and LibD, were also constructed and were mated to the EMS mutants. In all mating experiments, pVK 102 was conjugated to the mutants to serve as a negative control and to strain WS129 to serve as a positive control. The library pools (i.e. LibA-LibD) were also mated to strain WS129 to function as additional controls.

After conjugation, the cells were grown aerobically for 2-3 d on PYE/Tc plates to allow for the expression of tetracycline resistance. $T \mathrm{C}^{\mathrm{R}}$ colonies of $R$. sphaeroides were then replica plated onto malate and MSM solid media and grown for $5 \mathrm{~d}$ in a Gas-Pak anaerobic jar. Any resulting colonies were restreaked on fresh MSM and malate plates, along with the appropriate controls, and returned to the Gas-Pak for an additional 7-10 d with at least one change of the $\mathrm{H}_{2} / \mathrm{CO}_{2}$-generating envelope.

Mapping of complementing plasmid. Tn 5 insertions were used to pinpoint that part of the cloned DNA responsible for complementation. The $3.2 \mathrm{~kb}$ EcoRI-Pst I insert of pKW 1000 was first cloned into pRK 404, an RK2-derived plasmid encoding Tc resistance (Ditta et al., 1985). It thus provides a convenient cloning and expression vector which could be directly conjugated into $R$. sphaeroides. The cloning was accomplished by digestion of $\mathrm{pKW} 1000$ with EcoRI and Pst I followed by ligation to PstI-digested pRK404. The plasmid isolated from white colonies on plates of TYE plus 5-bromo-4-chloro-3-indolyl $\beta$-D-galactoside (X-Gal), isopropyl $\beta$-Dthiogalactoside (IPTG) and Tc was examined and the desired subclone identified. This subclone was then subjected to $\mathrm{Tn} 5$ insertion by the method of Berg et al. (1983). The resulting $\mathrm{Tc}^{\mathrm{R}} \mathrm{Km}^{\mathrm{R}}$ transformants were conjugated to strain KW25/11 by dotting $10 \mu \mathrm{l}$ of a transformant, $10 \mu \mathrm{l}$ of the mobilizing plasmid pRK2013, and $20 \mu \mathrm{l}$ of the photoheterotrophically grown mutant strain KW25/11 onto Millipore $1 \mathrm{~mm}$ filters placed on a PYE plate. After overnight growth, the filters were scraped with an inoculating loop and gridded onto PYE/Tc, Km, Sm plates. The resulting $R$. sphaeroides colonies were replica plated onto malate and MSM plates and checked for complementation. Plasmid DNA from the non-complementing transconjugants was isolated and the orientation of the Tn5 insertion determined.

General molecular biology procedures. Preparations of plasmid and chromosomal DNA from aerobically grown 
cultures of $R$. sphaeroides were obtained by the Sarkosyl lysate procedure of Figurski et al. (1976). Total $R$. sphaeroides DNA was extracted by the quick isolation procedure of Fornari \& Kaplan (1983). Small-scale plasmid isolations of $E$. coli were performed according to the procedure of Ish-Horowitz \& Burke (1981), while large-scale plasmid preparations were obtained by a scale-up of the rapid alkaline extraction procedure of Birnboim \& Doly (1979).

Restriction enzymes from New England Biolabs were used for all DNA digestions. Restriction buffers were made according to Maniatis et al. (1982). All plasmid DNA was digested with 5-10 units of enzyme ( $\mu \mathrm{g} D N A)^{-1}$ for $1-2 \mathrm{~h}$ at $37^{\circ} \mathrm{C}$. R. sphaeroides chromosomal and plasmid DNA was digested at $37^{\circ} \mathrm{C}$ overnight with $5-10$ units of enzyme ( $\mu \mathrm{g} \mathrm{DNA})^{-1}$ added initially, followed $4 \mathrm{~h}$ later by an additional 5-10 units. Agarose gel electrophoresis was performed in $0.8 \%$ agarose gels in Tris/acetate buffer as described by Maniatis et al. (1982). Ligations were performed for $2 \mathrm{~h}$ at $15^{\circ} \mathrm{C}$ with T4 DNA ligase obtained from New England Biolabs. Transformations were performed by the $\mathrm{MgCl}_{2} / \mathrm{CaCl}_{2}$ heat shock method as previously described (Cohen et al., 1972).

For Southern blotting, restricted DNA was transferred to GeneScreen Plus hybridization transfer membranes (New England Nuclear) by the capillary blot procedure of DuPont/NEN. Prehybridization was carried out at $42{ }^{\circ} \mathrm{C}$ for $1 \mathrm{~h}$ to overnight in $50 \%(\mathrm{v} / \mathrm{v})$ formamide, $10 \%(\mathrm{w} / \mathrm{v})$ dextran sulphate, $1 \%(\mathrm{w} / \mathrm{v})$ sodium dodecyl sulphate (SDS) and $1 \mathrm{M}-\mathrm{NaCl}$. All DNA probes were labelled with $\left[\alpha^{-32} \mathrm{P}\right] \mathrm{dCTP}\left(3200 \mathrm{Ci} \mathrm{mmol} ; 118.4 \mathrm{TBq} \mathrm{mmol}^{-1}\right)$ (New England Nuclear) by nick translation as described by Rigby et al. (1977) to specific activities of approximately $2 \times 10^{8}$ c.p.m. $\mu \mathrm{g}^{-1}$. Routinely, the respective probes were added to a final concentration of $10-15 \mathrm{ng} \mathrm{ml}^{-1}$. Hybridizations were carried out for 12-16 h, after which the blots were washed at high stringency in two changes of $2 \times \mathrm{SSC}$ for $5 \mathrm{~min}$ at room temperature, two changes of $2 \times \mathrm{SSC}, 0.1 \% \mathrm{SDS}$ for $30 \mathrm{~min}$ each at $65^{\circ} \mathrm{C}$ and two changes of $0.1 \% \mathrm{SSC}$ for $30 \mathrm{~min}$ each at room temperature [ $1 \times \mathrm{SSC}$ was $0.15 \mathrm{M}-\mathrm{NaCl}, 0.015 \mathrm{M}$-sodium citrate (pH 7.0)]. Without allowing the filters to dry completely, the blots were autoradiographed in a DuPont Lightningplus intensifying screen cassette with Kodak XAR-5 film and stored at $-70^{\circ} \mathrm{C}$. Exposure times varied from $4 \mathrm{~h}$ to $12 \mathrm{~h}$.

\section{RESULTS}

\section{Aut ${ }^{-}$mutant isolation after EMS treatment}

Following carbenicillin selection under photoautotrophic conditions, the survivors were plated onto malate and MSM media and screened for the Aut ${ }^{-}$phenotype. From the four separate EMS treatments, 29 presumptive Aut $^{-}$mutants were isolated after screening 400 colonies. Of these 29 , nine were confirmed Aut $^{-}$mutants, but all regained the ability for photolithoautotrophic growth upon successive subculturings. The nine confirmed Aut ${ }^{-}$mutants were subjected to additional carbenicillin selections. Survivors from this round of selection were again screened for the desired phenotype. This resulted in the isolation of two Aut ${ }^{-}$mutants which were exceedingly stable in their inability to grow photolithoautotrophically. The mutants grew normally on malate under photosynthetic conditions but were incapable of photosynthetic growth on butyrate/bicarbonate media. These mutant strains were designated EMS45 and EMS47.

There was some indication that complementation of the previously isolated Aut ${ }^{-}$mutant, strain $\mathrm{KW} 25 / 11$, required recombination of the complementing DNA fragment isolated from the $R$. sphaeroides gene bank (Weaver \& Tabita, 1985). Therefore, EMS mutagenesis was performed on the recA $R$. sphaeroides strain WS129 to determine if recombination was necessary for complementation. To confirm that the Aut ${ }^{-}$mutants, strain EMS45 and strain EMS47, had retained the $\operatorname{rec} A$ phenotype, their sensitivity to mitomycin $\mathrm{C}$ and metronidazole was tested (Willison \& Vignais, 1982). Strain WS22 (rec $A^{+}$parent of strain WS129) grew well on malate plates containing $200 \mu \mathrm{M}$-metronidazole, while strain WS129 and the Aut ${ }^{-}$mutants displayed only slight growth. In addition, both the Aut ${ }^{-}$mutants and strain WS129 were sensitive to as little as $0.05 \mu \mathrm{g}$ mitomycin $\mathrm{C} \mathrm{ml}^{-1}$ while strain WS22 grew well on plates containing $0.25 \mu \mathrm{g}$ mitomycin $\mathrm{C} \mathrm{ml}^{-1}$.

No significant differences were observed between the colony morphology of the mutant strains when grown on permissive media with the exception of a slightly more raised edge on strain EMS47 colonies. Strain EMS45 was indistinguishable from the parental strain. The mutants grew normally under photosynthetic conditions where RuBPC/O derepression is not necessary for growth. 


\section{Table 2. RUBPC/O activity after carbon starvation of mutant strains}

Cultures were inoculated with a $1 \%$ inoculum of washed malate-grown cells. RuBPC/O activities were determined by whole-cell assay (Tabita et al., 1978) and expressed as units per $\mathrm{OD}_{650}$ per litre of culture. Values are means of at least three determinations, $\pm \mathbf{S E}$.

\begin{tabular}{lcccc}
\multicolumn{1}{c}{ Strain } & OD $_{650}$ & $\begin{array}{c}\text { Initial } \\
\text { activity* }\end{array}$ & $\begin{array}{c}\text { Final } \\
\text { activity }\end{array}$ & $\begin{array}{c}\text { Fold activity } \\
\text { increase }\end{array}$ \\
WS129 & 1.83 & $4 \cdot 1 \pm 0 \cdot 5$ & $35 \cdot 0 \pm 3 \cdot 2$ & $8 \cdot 5$ \\
EMS45 & 1.86 & $4 \cdot 6 \pm 0 \cdot 8$ & $14 \cdot 6 \pm 1 \cdot 0$ & $3 \cdot 2$ \\
EMS47 & 1.87 & $3 \cdot 4 \pm 0 \cdot 5$ & $43 \cdot 3 \pm 4 \cdot 0$ & $12 \cdot 7$ \\
HR & 1.88 & $6 \cdot 1 \pm 0 \cdot 7$ & $33 \cdot 0 \pm 2 \cdot 0$ & $5 \cdot 4$ \\
KW25/11 & 1.88 & $7 \cdot 6 \pm 1 \cdot 0$ & $19 \cdot 0 \pm 1 \cdot 0$ & $2 \cdot 5$ \\
& $*$ RuBPC/O activity from malate-grown cells. \\
& † RuBPC/O activity from carbon-starved cells.
\end{tabular}

\section{Derepression of $R U B P C / O$ synthesis in mutant strains}

Since the $\mathrm{Aut}^{-}$mutants are unable to grow photolithoautotrophically, a system was devised to quantify the degree of derepression of RuBPC/O in these strains (Weaver \& Tabita, 1983). The wild-type strain HR is capable of increasing RuBP-dependent carboxylase activity six- to eightfold in the absence of exogenous carbon. Aut ${ }^{-}$mutant strain $\mathrm{KW} 25 / 11$ had previously been found to increase its carboxylase activity two- to fourfold under the same conditions (Weaver \& Tabita, 1983). Since no growth occurs without exogenous carbon, it is possible to compare the derepression capabilities of Aut $^{-}$mutant strains to that of their parental strains.

Carboxylase activities of the EMS mutant and wild-type strains after carbon starvation are presented in Table 2. Strain KW25/11 (Weaver \& Tabita, 1985) was included in all growth experiments for comparison to the newly isolated Aut ${ }^{-}$mutants. From the data it is apparent that strain EMS45, like strain $\mathrm{KW} 25 / 11$, is unable to derepress the synthesis of carboxylase to an extent equal to that of its parental strain WS129. Interestingly, strain EMS47, while unable to grow photolithoautotrophically or on butyrate/bicarbonate media, exhibits carboxylase levels somewhat above that of wild-type strain WS129. It should be noted that strain WS129 exhibits a greater degree of derepression under these conditions than wild-type strain HR, perhaps reflecting the different origins of these strains (Y. Jouanneau \& F. R. Tabita, unpublished observations). Strain WS129 typically increased the synthesis of RuBPC/O 8-11-fold compared to the 6-8-fold increase of strain HR.

\section{Rocket immunoelectrophoretic quantification of form I and form II protein}

While mutant strains KW25/11 and EMS45 showed similar increases in RuBPC/O activity in carbon-starved cells compared to malate-grown parental strains (Table 2) there was a marked variance of the levels of form I protein in strain EMS45 (Table 3), particularly in extracts of carbon-starved cells. From these results, it is apparent that the mutation in strain EMS45 differs from that in strain KW25/11. The mutation in strain EMS47 is different from both KW25/11 and EMS45. Although unable to grow photolithoautotrophically or in the butyrate/bicarbonate medium, strain EMS47 exhibited higher carboxylase activity than parental strain WS129, with nearly twice as much total $\mathrm{RuBPC} / \mathrm{O}$ antigen after carbon starvation (Table 3). This mutant also differs from strain $\mathrm{KW} 25 / 11$ in that it maintains a ratio of formI/form II of $3 \cdot 2$, very near the ratio exhibited by the wild-type.

\section{Complementation of strains EMS45 and EMS47}

Previously it was shown that plasmid pKWA200, which contains a DNA fragment isolated from a genomic library of strain HR, complemented strain KW25/11 and restored the capacity for autotrophic growth (Weaver \& Tabita, 1985). Plasmid pKWA200 did not complement mutant strains EMS45 and EMS47. In order to isolate the wild-type allele of the defective gene(s) responsible for the EMS mutations, the mutants were conjugated to a portion of the $R$. sphaeroides strain HR DNA library. Four independent matings (per library pool) to each of the 
Table 3. Immunological quantification of the derepression of RuBPC/O synthesis after carbon starvation of mutant strains

Extracts were prepared as described in Methods. Rocket electroimmunoassay was used to quantify the amount of form I and form II RuBPC/O, which is expressed as a percentage of the total soluble protein (Jouanneau \& Tabita, 1986). Values are means of at least three determinations, $\pm \mathrm{SE}$.

\begin{tabular}{|c|c|c|c|c|}
\hline \multirow[b]{2}{*}{ Strain } & \multirow{2}{*}{$\begin{array}{l}\text { Carbon } \\
\text { source }\end{array}$} & \multicolumn{2}{|c|}{$\begin{array}{l}\text { Amount of } \mathrm{RuBPC} / \mathrm{O} \text { protein } \\
(\% \text { extract protein })\end{array}$} & \multirow{2}{*}{$\begin{array}{c}\text { Ratio } \\
\text { form } I / \text { form II }\end{array}$} \\
\hline & & Form I & Form II & \\
\hline WS129 & Malate & $0.32 \pm 0.04$ & $0.74 \pm 0.04$ & 0.43 \\
\hline EMS45 & Malate & $0.16 \pm 0.03$ & $0.44 \pm 0.07$ & $0 \cdot 36$ \\
\hline EMS47 & Malate & $0.08 \pm 0.01$ & $0.56 \pm 0.04$ & $0 \cdot 14$ \\
\hline HR & Malate & $0.48 \pm 0.05$ & $0.80 \pm 0.04$ & 0.60 \\
\hline $\mathrm{KW} 25 / 11$ & Malate & $0.48 \pm 0.05$ & $1.24 \pm 0.05$ & $0 \cdot 39$ \\
\hline WS129 & Carbon starved & $9 \cdot 3 \pm 0.8$ & $2 \cdot 7 \pm 0 \cdot 5$ & 3.44 \\
\hline EMS45 & Carbon starved & $5 \cdot 0 \pm 0 \cdot 4$ & $1 \cdot 3 \pm 0.3$ & 3.85 \\
\hline EMS47 & Carbon starved & $16 \cdot 0 \pm 1 \cdot 0$ & $5 \cdot 0 \pm 0.5$ & $3 \cdot 20$ \\
\hline HR & Carbon starved & $8 \cdot 0 \pm 0.5$ & $4.0 \pm 0.5$ & $2 \cdot 00$ \\
\hline KW25/11 & Carbon starved & $4 \cdot 0 \pm 0 \cdot 3$ & $4 \cdot 7 \pm 0 \cdot 4$ & 0.85 \\
\hline
\end{tabular}

EMS mutants were accomplished. Three to four complemented transconjugants were identified from each of the matings of LibA to strain EMS45, while none were obtained from matings of this mutant to the other library pools. Strain EMS47 was not complemented by LibA, but instead was found to be complemented by LibB. Strain EMS47 did not develop any other complemented transconjugants after mating to LibD or LibC. Two complementing transconjugants from each mating were randomly chosen and their plasmid purified. The pVK102 hybrid was then separated from the endogenous $R$. sphaeroides plasmids by transformation of E. coli RM1058 to Tc resistance. Plasmid DNA samples purified from complemented strains of strain EMS45 were found to be identical and designated pMRA100. Plasmids purified from the complemented strains of strain EMS47 were designated pMRB500. On the basis of restriction mapping, these plasmids were distinctly different from the pVK 102 hybrid isolated from complemented strains of $\mathrm{KW} 25 / 11$. This would further indicate that these strains possess different mutations which manifest the Aut ${ }^{-}$phenotype. As a control, and to determine if the incomplete complementation of strain $\mathrm{KW} 25 / 11$ might be relieved by isolation of a library fragment other than pKWA200, the complemented transconjugants of this mutant were also picked and the plasmid DNA purified. All plasmid profiles from these transconjugants, after transformation of $E$. coli RM1058, were identical to pKWA200. A partial restriction map of pMRA100, pMRB500 and pKWA200 is presented in Fig. 1.

\section{Mapping of $p K W 1000$ by Tn5 transpositional inactivation of the complementing DNA}

The previous gene bank isolate, pKWA200, had been subcloned and the complementing DNA found to reside on a $2.7 \mathrm{~kb}$ Pst I fragment. A $3.2 \mathrm{~kb} E c o \mathrm{RI}-$ PstI clone of this fragment had been inserted into the expression vector, pUC8, generating pKW1000 (Weaver \& Tabita, 1985). Subsequent digestion of the plasmid with various restriction enzymes revealed four $X$ hoI sites and numerous BamHI sites. Subcloning of the XhoI fragments resulted in loss of complementation. The exact portion of the DNA responsible for the complementation was mapped by inactivation of the $3.2 \mathrm{~kb}$ fragment with $\mathrm{Tn} 5$ insertions. To facilitate identification of Tn 5 -inactivated subclones, the $3.2 \mathrm{~kb} E c o \mathrm{RI}-P s t \mathrm{I}$ insert was cloned into pRK404, subjected to $\mathrm{Tn} 5$ mutagenesis, and the resultant transformants conjugated to strain $\mathrm{KW} 25 / 11$ followed by replica plating onto MSM and malate plates. Plasmid DNA from the non-complementing transconjugants was isolated and the orientation of the Tn 5 insertion determined. The complete map of the complementing plasmid is shown in Fig. 2. The portion of the DNA responsible for the complementation of strain $\mathrm{KW} 25 / 11$ is carried on a $1.5 \mathrm{~kb}$ BamHI-Pst I fragment since only Tn5 inserts in this region disrupt complementation. 


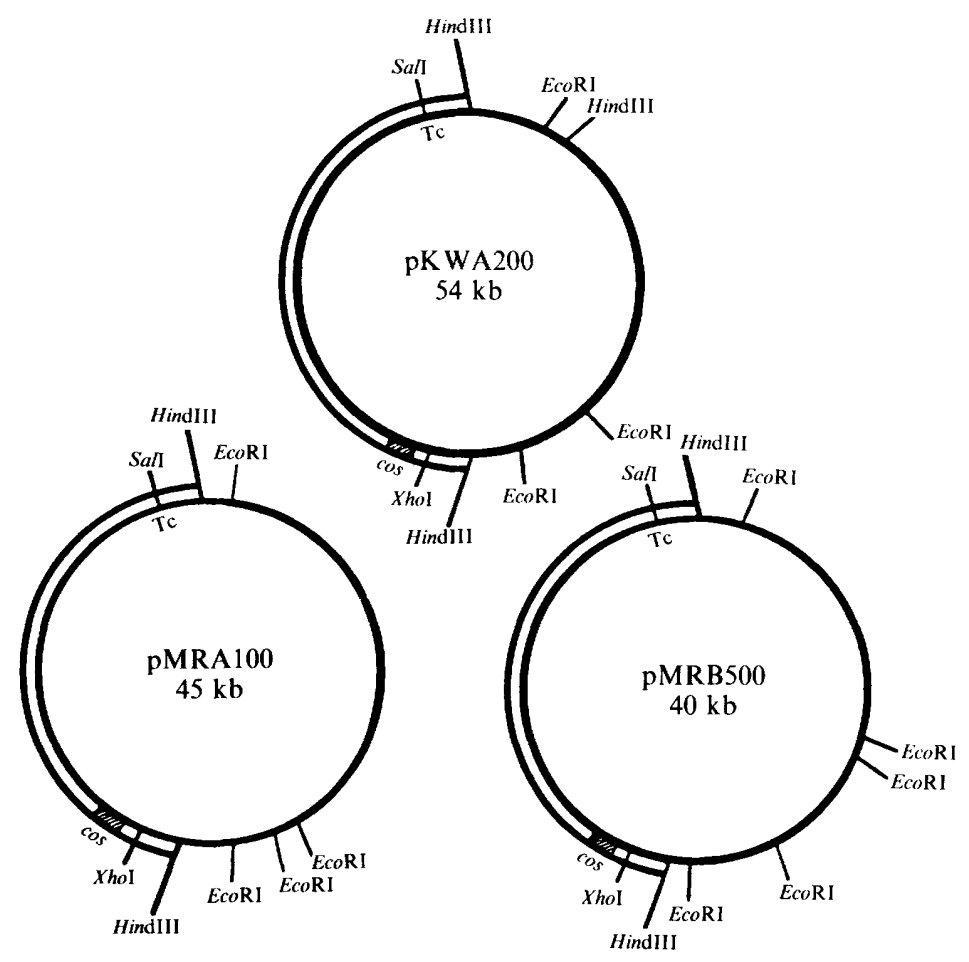

Fig. 1. Partial restriction map of pKWA200, pMRA100, and pMRB500. A single line indicates the inserted fragment; a double line represents vector sequences. Plasmid pVK $102 \mathrm{Sall}$ and $\mathrm{XhoI}$ sites are included for purposes of orientation.

\section{Southern hybridization using complementing library isolates as probes}

Chromosomal and plasmid DNA from $R$. sphaeroides strain HR was digested with EcoRI, blotted, and then probed with the complementing library fragments to determine if these fragments are normally carried on the plasmid or chromosome of $R$. sphaeroides. As a control, plasmids pJG106 and pJG336 were also used to probe the $R$. sphaeroides chromosomal and plasmid DNA. Plasmid pJG336 contains a cluster of five structural genes important for $\mathrm{CO}_{2}$ fixation, including the form I RuBPC/O genes (Gibson \& Tabita, 1986, 1987, 1988). Plasmid pJG106, isolated from the strain HR DNA library, contains the second cluster of $\mathrm{CO}_{2}$ fixation structural genes (form II genes). Repeated hybridizations of $R$. sphaeroides chromosomal and plasmid DNA with pJG336 (results not shown) and pJG106 (Fig. 3) as probes consistently indicated that the form I and form II structural genes were located on the chromosome. Plasmids pJG336 and pJG106 never hybridized to plasmid DNA from strain HR, despite using considerably higher concentrations of plasmid DNA than chromosomal DNA in several experiments of this type. Thus, there was little cross-contamination between the chromosomal DNA and the endogenous plasmid DNA in these preparations of $R$. sphaeroides DNA. Results of Southern hybridizations, using the various complementing fragments as probes, indicated that plasmid pKWA200 displayed hybridization to strain HR plasmid DNA, with bands of approximately $26,25,23$ and $9 \cdot 0 \mathrm{~kb}$ (Fig. 3). Plasmid pMRA100 also hybridized to the strain HR plasmid DNA, producing bands of about 23,14 and $9.7 \mathrm{~kb}$, as did plasmid pMRB500, which hybridized to $23,13.5,9.2,8.8,4.3$ and $3.6 \mathrm{~kb}$ EcoRI fragments. Clearly, all the complementing library fragments, thus far isolated, are encoded by the endogenous plasmid of $R$. sphaeroides strain $\mathrm{HR}$. 

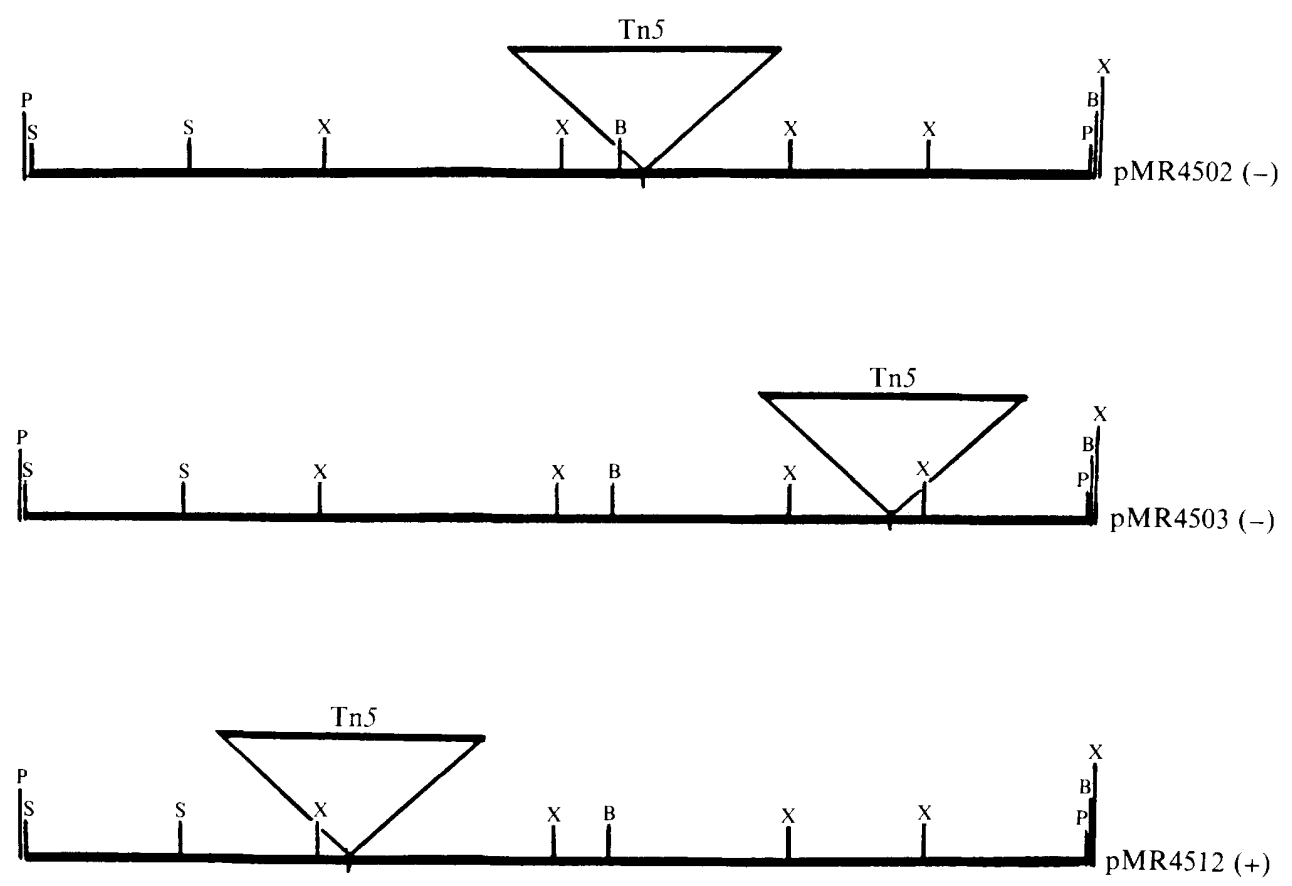

$1 \cdot 0 \mathrm{~kb}$

Fig. 2. Mapping, by $\operatorname{Tn} 5$ transpositional inactivation, of the $3 \cdot 2 \mathrm{~kb} R$. sphaeroides DNA fragment complementing Aut ${ }^{-}$strain $\mathrm{KW} 25 / 11$. Complementing DNA was identified by $\mathrm{Tn} 5$ insertions which resulted in loss of complementation ability: (+), positive complementation; (-), negative complementation. DNA responsible for complementation is carried on a 1.5 Bam HI-Pst I fragment. Restriction enzyme sites: P, PstI; S, SaII; B, BamHI; X, XhoI.

\section{Derepression of $R u B P C / O$ in complemented strains}

The complemented mutants, strain EMS45(pMRA100) and strain EMS47(pMRB500), were grown photolithoautotrophically on MSM media bubbled with $1.5 \% \mathrm{CO}_{2}$ in $\mathrm{H}_{2}$. Strains KW25/11(pKWA200), HR and WS129 were included in the growth experiment as controls. Strains HR and WS129, containing the library vector pVK102, were also grown photolithoautotrophically in order to assess the effect of this plasmid on the growth and metabolic characteristics of $R$. sphaeroides. Plasmid pVK102 was maintained in the parental strains by the addition of $25 \mu \mathrm{g} \mathrm{Km} \mathrm{ml}{ }^{-1}$ to the MSM media. Antibiotics, except for the addition of Sm to strain KW25/11(pKWA200) and strain HR cultures, were omitted since it was determined that the presence of the light-sensitive antibiotic Tc in photosynthetic growth media tended to inhibit growth. Although $\mathrm{Km}$ was used to maintain the plasmid mated into the parental strains, the gene encoding $\mathrm{Km}$ resistance has been inactivated in the library hybrids. The absence of antibiotic selection was not considered a hindrance to assessment of complementation since the mutants are normally incapable of photolithoautotrophic growth under $1.5 \% \mathrm{CO}_{2}$ in $\mathrm{H}_{2}$. Thus, only complemented mutants would be able to grow under these conditions.

The complemented mutants invariably exhibited longer lag phases than either the wild-type strains or the parental strains conjugated to pVK102, which possessed only slightly longer lag phases than strain HR or strain WS129. It appears that the presence of pVK 102 in the parental strains does have some effect on the derepression of carboxylase, although the lower carboxylase levels in these cells does not account for the incomplete complementation observed in strain EMS47(pMRB500) or strain KW25/11(pKWA200) (Table 4). Interestingly, strain 


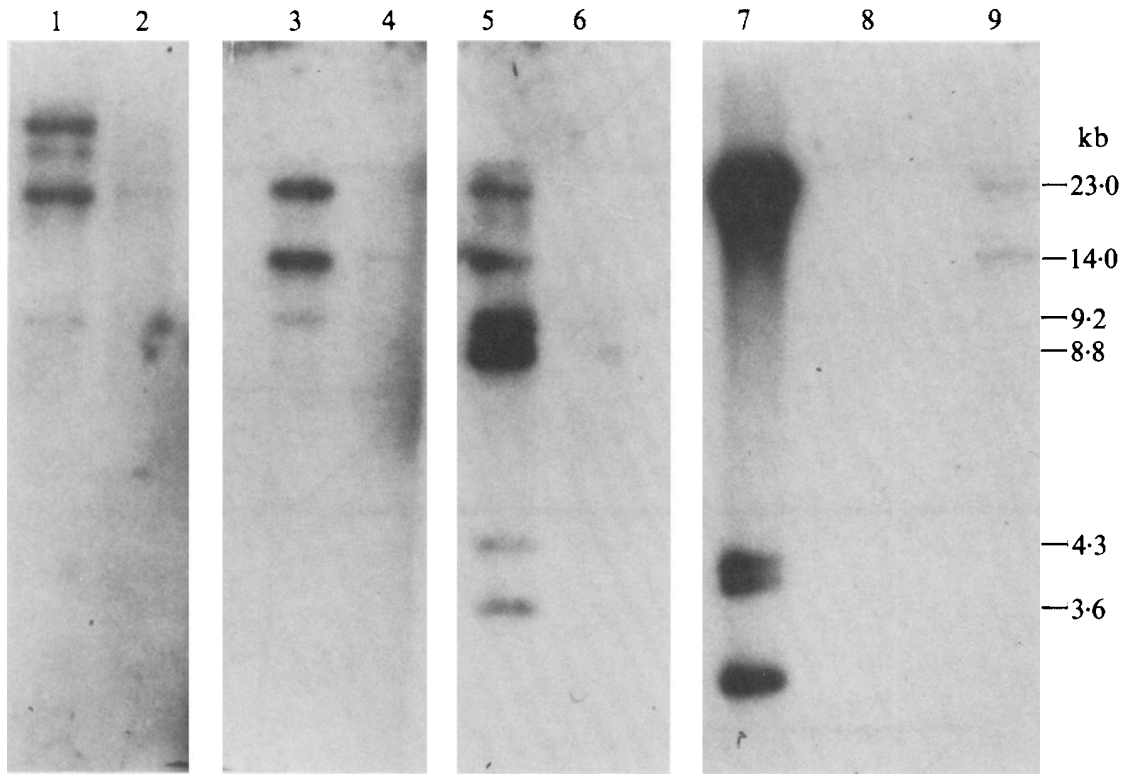

Fig. 3. Southern hybridization analysis of $R$. sphaeroides strain HR plasmid and chromosomal DNA using complementing library fragments as probes. All DNA was digested with EcoRI. Lane 1, plasmid DNA from strain HR, probed with pKWA 200; lane 2, chromosomal DNA from strain HR, probed with pKWA200; lane 3, plasmid DNA from strain HR, probed with pMRA100; lane 4, chromosomal DNA from strain HR probed with pMRA100; lane 5, plasmid DNA from strain HR probed with pMRB500; lane 6, chromosomal DNA from strain HR probed with pMRB500; lane 7, plasmid pJG106 probed with pJG106; lane 8, plasmid DNA from strain HR probed with pJG106; lane 9, chromosomal DNA from strain HR probed with pJG106. Hybridizations were carried out under stringent conditions (i.e. $50 \%$ formamide at $65^{\circ} \mathrm{C}$ ).

\section{Table 4. Derepression of $R U B P C / O$ of complemented mutants after autotrophic growth}

Large-scale cultures were initiated with a $1 \%$ inoculum of washed photoheterotrophically (malate)grown cells except for complemented mutant cultures which were started with $1 \%$ inoculum of washed aerobically (malate)-grown cells. Extracts were prepared as described in Methods. Values are means of at least three determinations, $\pm \mathrm{SE}$.

\begin{tabular}{|c|c|c|c|c|}
\hline \multirow[b]{2}{*}{ Strain } & \multirow{2}{*}{$\begin{array}{c}\text { RuBPC/O } \\
\text { specific } \\
\text { activity* }\end{array}$} & \multicolumn{2}{|c|}{$\begin{array}{l}\text { Amount of RuBPC/O protein } \\
(\% \text { extract protein }) \dagger\end{array}$} & \multirow{2}{*}{$\begin{array}{c}\text { Ratio } \\
\text { form } I / \text { form } I\end{array}$} \\
\hline & & Form I & Form II & \\
\hline WS129 & $0.40 \pm 0.05$ & $10.6 \pm 1.0$ & $3 \cdot 5 \pm 0 \cdot 6$ & 3.03 \\
\hline WS129(pVK102) & $0.30 \pm 0.04$ & $7 \cdot 5 \pm 0.8$ & $2 \cdot 2 \pm 0 \cdot 2$ & $3 \cdot 40$ \\
\hline EMS45(pMRA100) & $0.31 \pm 0.05$ & $7 \cdot 0 \pm 0.7$ & $3 \cdot 3 \pm 0.3$ & $2 \cdot 12$ \\
\hline EMS47(pMRB500) & $0.21 \pm 0.05$ & $2 \cdot 8 \pm 0.5$ & $1 \cdot 2 \pm 0 \cdot 3$ & $2 \cdot 33$ \\
\hline $\mathrm{HR}$ & $0 \cdot 34 \pm 0 \cdot 06$ & $7 \cdot 2 \pm 0 \cdot 8$ & $3 \cdot 2 \pm 0.8$ & $2 \cdot 25$ \\
\hline $\mathrm{HR}(\mathrm{p} V K 102)$ & $0 \cdot 28 \pm 0.06$ & $6 \cdot 0 \pm 0.5$ & $3 \cdot 1 \pm 0 \cdot 5$ & 1.94 \\
\hline KW25/11(pKWA200) & $0.20 \pm 0.07$ & $4 \cdot 2 \pm 0 \cdot 4$ & $3 \cdot 0 \pm 0 \cdot 5$ & 1.40 \\
\hline
\end{tabular}

* Units (mg protein) ${ }^{-1}$.

$\dagger$ Rocket electroimmunoassay was used to quantify the amounts of form I and form II RuBPC/O (see Table 3). Soluble extract protein concentration was determined by Lowry protein assay (Markwell et al., 1978).

EMS45(pMRA100) was able to achieve a specific activity equivalent to EMS45(pVK 102). Mutant EMS45(pMRA100) displayed complemented carboxylase activities above those achieved by any of the other complemented mutants. Strain EMS47(pMRB500) exhibited levels below that of strain WS129 or strain WS129(pVK102). This is somewhat surprising since this mutant displayed activities $1 \cdot 25$-fold above that of wild-type under carbon starvation 
conditions. The library fragment allowing for photolithoautotrophic growth of strain EMS47 appears to partially relieve the mutation. Strain HR(pVK102) had a specific activity somewhat lower than strain HR. This reduction in carboxylase levels due to the vector, however, does not appear to compensate for the incomplete complementation of strain KW25/11(pKWA200).

\section{DISCUSSION}

It was originally assumed that the inability to synthesize sufficient RuBPC/O levels, in particular form I, was responsible for the lack of autotrophic growth (Weaver \& Tabita, 1985). More recent studies with $R$. sphaeroides strains in which either the form I or form II RuBPC/O structural genes were replaced with $\mathrm{Tn} 5$-inactivated clones, or inactivated by insertion of an antibiotic resistance marker in the coding sequence, have shown this assumption to be incorrect. Strains containing either the inactivated form I or form II RuBPC/O genes are capable of photolithoautotrophic growth (Falcone et al., 1988), indicating that the inability to derepress the synthesis of form I or form II cannot be immediately responsible for the Aut ${ }^{-}$phenotype. It must be concluded, therefore, that the mutational phenotype stems from a deficiency in some aspect of autotrophic growth other than the direct regulation of RuBPC/O synthesis. However, the mutations do result in altered levels of either form I or form II, or both, suggesting an indirect effect on the regulation of carboxylase derepression.

It appears that mutant strain $\mathrm{KW} 25 / 11$ is unable to increase its carboxylase activities to an extent equal to that of the wild-type due to insufficient production of form I RuBPC/O under carbon starvation. The increased form II levels in this mutant may represent an attempt by the cells to compensate for the reduction in form I levels. Thus, the mutation may be involved in some aspect of photolithoautotrophic growth that results in an alteration of the derepression of both forms of RuBPC/O, with form I being somewhat more affected than form II.

Examination of the increases in enzyme levels of each form of RuBPC/O in carbon-starved strain EMS45 shows a marked difference from that found in strain $\mathrm{KW} 25 / 11$. Extracts of malate-grown strain EMS45 contain only half the levels of form I and form II RuBPC/O as the parental strain WS129. Extracts of malate-grown strain KW25/11, on the other hand, possess equivalent amounts of form I and 1.5 times the amount of form II present in parental strain HR. These differences are even more evident in extracts of carbon-starved cells, where strain EMS45 has approximately $54 \%$ of the form I RuBPC/O found in parental strain WS129; under the same conditions, strain $\mathrm{KW} 25 / 11$ also has $50 \%$ of the form I RuBPC/O of its parental strain HR, but $118 \%$ of the form II RuBPC/O levels. Therefore, strain EMS45 contains an Aut $^{-}$mutation which results in lower concentrations of both $\mathrm{RuBPC} / \mathrm{O}$ forms and from the results reported here, it appears that strain EMS45 possesses a somewhat different mutation than that found in strain KW25/11.

The mutation in strain EMS47 is quite different from either of the other two mutants. Although unable to grow photolithoautotrophically or on butyrate/bicarbonate medium, this mutant has higher carboxylase activities than strain WS129, with nearly twice as much total $\mathrm{RuBPC} / \mathrm{O}$ antigen after carbon starvation. The mutation, while involving some aspect of photolithoautotrophic growth, does not exhibit the characteristics of a regulatory mutation. It is possibly a $\mathrm{CO}_{2}$ transport mutation or involves a mutation in some other aspect of autotrophic growth. The excessive levels of carboxylase may reflect an attempt by the cells to accumulate $\mathrm{CO}_{2}$, which would be severely limited in transport-deficient cells. Mutant strain EMS47 maintains a ratio of form I/form II of 3.2, very near that of the wild-type strain WS129; this ratio changes in mutant strain EMS45 to 3.9 while mutant strain $\mathrm{KW} 25 / 11$ exhibits a form I/form II ratio of $0 \cdot 85$. This ratio is definitely strain dependent since the normal ratio of formI/form II for strain HR (the parental strain of mutant strain KW25/11) is 0.5 for malate-grown cells and approximately $2 \cdot 0$ for autotrophically grown cells (Jouanneau \& Tabita, 1986), while the ratio in strain WS129 is $0 \cdot 4$ and $3 \cdot 2-3 \cdot 4$, respectively.

Complementing library fragments, which enable all three mutant strains to grow photolithoautotrophically, are localized on one of the endogenous plasmids of $R$. sphaeroides. Although the two parental strains (strain HR and strain WS129) have different plasmid profiles, 
it has been shown that the large endogenous plasmids in $R$. sphaeroides strains are essentially homologous (Fornari et al., 1984). Thus, a gene isolated from the DNA library of strain HR would be capable of complementing mutants derived from strain WS129, even if the disrupted gene is maintained on the endogenous plasmids. If regulatory regions are indeed plasmid-borne, then the difference in plasmid profiles could be responsible for the differences in form I/form II ratios between these two strains under the same growth conditions. The only genes so far identified on the endogenous plasmids of $R$. sphaeroides (Nano \& Kaplan, 1984) have been concerned with the photosynthetic apparatus; other genes involved in autotrophic growth may be contained here as well. Nano \& Kaplan (1984) found that introduction of Mu dl (Ap lac) into $R$. sphaeroides via plasmid $\mathrm{R} 751$ resulted in the isolation of photosynthetic deficient $\left(\mathrm{Pho}^{-}\right)$ mutants. The $\mathrm{Pho}^{-}$mutants were invariably found to have alterations in their endogenous plasmid profiles. The genes complementing the Aut ${ }^{+}$mutants in this study all appear to be carried on the endogenous plasmids of $R$. sphaeroides. For reasons that are not clear, the mutant isolation selection procedure (photoheterotrophic growth on malate media, but no growth on MSM or butyrate/bicarbonate media) seems to select for mutations which, at least in the EMS mutant strains and strain $\mathrm{KW} 25 / 11$, are complemented by plasmid genes. If other genes involved in autotrophic growth are contained on the endogenous plasmids, disruption of these could result in the Aut ${ }^{-}$phenotype. It is also possible that some of the plasmid genes represent duplications of chromosomal genes. Such gene duplications have been identified in A. eutrophus (Andersen \& Wilke-Douglas, 1984). Willison et al. (1987) have recently developed a plasmid-less strain of $R$. capsulatus which exhibits homologous sequences between the plasmid and chromosome in this organism, although it is not clear if these are indeed gene duplications. The complementing library isolates hybridize strongly to the plasmid fraction of $R$. sphaeroides, although faint ghost bands can be seen in the chromosomal lanes. This could be due to some slight contamination of the chromosomal DNA with plasmid DNA or represent some homology between the plasmid and chromosomal DNA. Further hybridization studies in these mutants to determine the types of mutation are impeded since the vast majority of EMS-induced mutations are undetectable by Southern blot analysis (Stankowski et al., 1986). Strain KW25/11, although generated by an alternative mutagenesis procedure, failed to show any obvious changes in hybridization patterns when compared to its parental strain.

It is quite possible that some of these mutations may require recombination of the complementing gene before growth can be accomplished photolithoautotrophically. Strain $\mathrm{KW} 25 / 11$ exhibits an extensive lag before growth under these conditions. It should be noted that these strains are indeed complemented and not mere revertants since pVK102 failed to complement the mutations in strains EMS45 and EMS47 or in strain KW25/11 (Weaver \& Tabita, 1985) and repeated matings of the complementing genes into these strains have invariably yielded results inconsistent with the random isolation of revertants. Strain EMS45 and strain EMS47 were isolated by mutagenesis of the recombination-deficient strain WS129. Repeated checks of these mutants have shown the retention of their original RecA ${ }^{-}$phenotype. Complementation of strain EMS45 must occur without recA-regulated recombination, and is most likely due to a trans-acting factor, while the poor complementation of strain EMS47 may be due, in part, to lack of recombination (i.e. it needs a cis-acting factor). It is also apparent that the complementing clones do not represent classical regulatory genes which might be contained within the RuBPC/O operons. It is likely that the alteration of RuBPC/O synthesis in these mutant strains is a consequence of some mutation that affects general photolithoautotrophic growth.

Complemented mutants, after a lag phase, are able to grow photolithoautotrophically at approximately the same rate as their parental strains, yet appear to be unable (with one possible exception) to completely derepress the synthesis of $\mathrm{RuBPC} / \mathrm{O}$ equivalent to their parental strains. This partial complementation has also been noted in some Aut ${ }^{-}$mutants of Alcaligenes eutrophus. Andersen \& Wilke-Douglas (1987) isolated two Aut ${ }^{-}$mutants, one which was discovered to be mutated in the $r b c L$ structural gene. This mutant regained wild-type activity when conjugated to the cloned $r b c L$ gene. A second Aut $^{-}$mutant was unable to be complemented to wild-type carboxylase levels even though it was believed to contain a mutation 
in the small subunit of $\mathrm{RuBPC} / \mathrm{O}$. Interference from the mutant $\mathrm{RuBPC} / \mathrm{O}$ was hypothesized to be responsible for the lack of complete complementation. The Aut ${ }^{-}$mutants of $R$. sphaeroides may also produce some sort of mutant proteins which could interfere with gene product(s) produced by the complementing library fragments. It is also possible that the complementing clones do not contain all the genetic information necessary to relieve the mutation or, perhaps, these strains may harbour additional mutations. Conversely, the apparent partial complementation could be a consequence of the introduction of the donor vector, pKV102, into the cells. Physiological effects of exogenous plasmid DNA in other organisms have been well documented. Introduction of broad-host-range plasmids related to pVK102 into Azobacter vinelandii resulted in a variety of altered physiological properties (Glick et al., 1985) and other plasmid-containing bacterial cells have been reported to exhibit slower growth rates than plasmid-free cells, presumably due to an increased 'metabolic load' (Siegal \& Ryu, 1985). Conjugation of pVK 102 into the parental strains of the $\mathrm{Aut}^{-}$mutants did result in a variance in RuBPC/O levels; however, only strain EMS45 was able to achieve complemented carboxylase levels equivalent to strain WS129(pVK 102). This mutant seems to be fully complemented, whereas strain KW25/11 and strain EMS47 seem to be only partially complemented.

In summary, complementing genes have been isolated which are involved with some aspect of $\mathrm{CO}_{2}$-dependent growth in the light. Further characterization of these genes and any gene products they may produce should greatly enhance our understanding of the intricate mechanisms these organisms utilize to regulate facultative autotrophic growth. The apparent localization of these genes on endogenous plasmid DNA is particularly intriguing. Other Aut $^{-}$ mutants created by $\operatorname{Tn} 5$ mutagenesis and other means are currently being characterized.

This research was supported by US Public Health Service grant GM24497 from the National Institutes of Health.

\section{REFERENCES}

ANDERSEN, K. \& VAlENTINe, R. C. (1982). Genetic Engineering of Microorganisms for Chemicals, pp. 446-458. Edited by A. Hollaender, R. D. De Moss, S. Kaplan, J. Konisky, D. Savage \& R. S. Wolfe. New York: Plenum Press.

Andersen, K. \& Wilke-Douglas, M. (1984). Construction and use of a gene bank of Alcalignes eutrophus in the analysis of ribulose bisphosphate carboxylase genes. Journal of Bacteriology 159, 973-978.

Andersen, K. \& Wilke-Douglas, M. (1987). Genetic and physical mapping and expression in Pseudomonas aeruginosa of the chromosomally encoded ribulose bisphosphate carboxylase gene of Alcaligenes eutropus. Journal of Bacteriology 169, 1997-2004.

BerG, D. E., Schmandt, M. A. \& Lowe, J. B. (1983). Specificity of transposon Tn 5 insertion. Genetics 105, 813-828.

Birnboim, H. C. \& Doly, J. (1979). A rapid alkaline extraction procedure for screening recombinant plasmid DNA. Nucleic Acids Research 7, 1513-1517.

Bowien, B., Friedrich, B. \& FrIEdRICH, C. G. (1984). Involvement of megaplasmids in heterotrophic derepression of the carbon dioxide assimilating enzyme system in Alcaligenes spp. Archives of Microbiology 139, 305-310.

Boyer, H. B. \& Roulland-Sussaiz, D. (1969). A complementation analysis of the restriction and modification of DNA in Escherichia coli. Journal of Molecular Biology 41, 459-472.
Cohen, S. N., Chang, A. C. Y. \& Hsu, L. (1972). Nonchromosomal antibiotic resistance in bacteria: genetic transformation of Escherichia coli by $\mathbf{R}$ factor DNA. Proceedings of the National Academy of Sciences of the United States of America 69, 2110-2114.

DitTa, G., Schmidhauser, T., Yakoboson, E., LU, P., Liang, X., Finaly, D., Guiney, D. \& Helinski, D. R. (1985). Plasmids related to the broad host range vector pRK 290 useful for gene cloning and for monitoring gene expression. Plasmid 13, 149-153.

Dow, C. S. (1987). $\mathrm{CO}_{2}$ fixation in Rhodopseudomonas blastica. In Microbial Growth on $C_{1}$ Compounds, pp. 28-37. Edited by H. W. Van Verseld \& J. A. Duine. Dordrecht: Martinus Nijhoff.

Falcone, D. L., Quivey, R. G., JR \& Tabita, F. R. (1988). Transposon mutagenesis and physiological analysis of strains containing inactivated form I and form II ribulose bisphosphate carboxylase/oxygenase genes in Rhodobacter sphaeroides. Journal of Bacteriology 170, 5-11.

FIgURSKI, D. \& HelinSKI (1979). Replication of an origin-containing derivative of the plasmid RK2 dependent on a plasmid function provided in trans. Proceedings of the National Academy of Sciences of the United States of America 76, 1648-1652.

Figurski, D., MEYer, R., Miller, D. S. \& HelinsKi, D. R. (1976). Generation in vitro of deletions in the broad host range plasmid RK2 using phage $\mathrm{Mu}$ insertions and a restriction endonuclease. Gene 1 , 107-119. 
FoRNARI, C. S. \& KaPLAN, S. (1983). Identification of nitrogenase and carboxylase genes in the photosynthetic bacteria and cloning of a carboxylase gene from Rhodopseudomonas sphaeroides. Gene 25, 291-299.

Fornari, C. S., Watkins, M. \& Kaplan, S. (1984). Plasmid distribution and analysis in Rhodopseudomonas sphaeroides. Plasmids 11, 39-47.

Gibson, J. L. \& TABITA, F. R. (1977a). Different molecular forms of D-ribulose 1,5-bisphosphate carboxylase from Rhodopseudomonas sphaeroides. Journal of Biological Chemistry 252, 943-949.

Gibson, J. L. \& Tabita, F. R. (1977b). Characterization of antiserum directed against form 11 ribulose 1,5-bisphosphate carboxylase from Rhodopseudomonas sphaeroides. Journal of Bacteriology 131, 1020 1022.

Gibson, J. L. \& TABiTA, F. R. (1977c). Isolation and preliminary characterization of two forms of ribulose 1,5-bisphosphate carboxylase from Rhodopseudomonas capsulata. Journal of Bacteriology 132, 818-823.

Gibson, J. L. \& TABITA, F. R. (1986). Isolation of the Rhodopseudomonas sphaeroides form I ribulose 1,5bisphosphate carboxylase/oxygenase large and small subunit genes and expression of the active hexadecameric enzyme in Escherichia coli. Gene 44, 271-278.

Gibson, J. L. \& Tabita, F. R. (1987). Organization of phosphoribulokinase and ribulose bisphosphate carboxylase/oxygenase genes in Rhodopseudomonas (Rhodobacter) sphaeroides. Journal of Bacteriology 169, 3685-3690.

Gibson, J. L. \& TABiTA, F. R. (1988). Localization and mapping of $\mathrm{CO}_{2}$ fixation genes within two gene clusters in Rhodobacter sphaeroides. Journal of Bacteriology 170, 2153-2158.

Glick, B. R., Brooks, H. E. \& Pasternak, J. J. (1986). Physiological effects of plasmid DNA transformation on Azotobacter vinelandii. Canadian Journal of Microbiology 32, 145-148.

Hallenbeck, P. \& Kaplan, S. (1987). Cloning of the gene for phosphoribulokinase activity from Rhodobacter sphaeroides and its expression in Escherichia coli. Journal of Bacteriology 169, 3669-3678.

IsH-HoRowitz, D. \& BURKE, J. F. (1981). Rapid and efficient cosmid vector cloning. Nucleic Acids Research 9, 2989-2998.

JouanneaU, Y. \& TABita, F. R. (1986). Independent regulation of synthesis of form I and form II ribulose bisphosphate carboxylase-oxygenase in Rhodopseudomonas sphaeroides. Journal of Bacteriology 165 , 620-624.

KNAuf, V. C. \& Nester, E. W. (1982). Wide host range cloning vectors: a cosmid clone bank of an Agrobacterium Ti plasmid. Plasmid 8, 45-54.

Maniatis, T., Fritsch, E. F. \& Sambrook, J. (1982). Molecular Cloning: a Laboratory Manual. Cold Spring Harbor, NY: Cold Spring Harbor Laboratory.

Markwell, M. A., Hass, S. M., Buber, L. L. \& TOLBERT, N. E. (1978). A modification of the Lowry procedure to simplify protein determination in membrane and lipoprotein samples. Analytical Biochemistry 87, 206-210.

MARRS, B. (1981). Mobilization of the genes for photosynthesis from Rhodopseudomonas capsulata by a promiscuous plasmid. Journal of Bacteriology 146 , $1003-1012$

Miziorko, H. M. \& Lorimer, G. H. (1983). Ribulose 1,5-bisphosphate carboxylase-oxygenase. Annual Review of Biochemistry 52, 507-535.

Muller, E. D., Chory, J. \& Kaplan, S. (1985). Cloning and characterization of the gene product of the form II ribulose 1,5-bisphosphate carboxylase gene of Rhodopseudomonas sphaeroides. Journal of Bacteriology 161, 469-472.

NANO, F. E. \& KaPlan, S. (1984). Plasmid rearrangements in the photosynthetic bacterium Rhodopseudomonas sphaeroides. Journal of Bacteriology 158, 1094-1103.

Ormerod, J. G., Ormerod, K. D. \& Gest, H. (1961). Light dependent utilization of organic compounds and photoproduction of hydrogen by photosynthetic bacteria: relationship with nitrogen metabolism. Archives of Biochemistry and Biophysics 94, 449-463.

Quivey, R. G., JR \& TABITA, F. R. (1984). Cloning and expression in Escherichia coli of the form II ribulose 1,5 bisphosphate carboxylase/oxygenase gene from Rhodopseudomonas sphaeroides. Gene 31, 91-101.

Rigby, P. W. J., Deickmann, M., Rhodes, C. \& Berg, P. (1977). Labeling deoxyribonucleic acid to high specific activity in vitro by nick translation with DNA polymerase I. Journal of Molecular Biology 113, 237-251.

Shively, J. M., Davidson, T. \& Marrs, B. L. (1984). Derepression in the synthesis of the intermediate and large forms of ribulose 1,5-bisphosphate carboxylase/oxygenase in Rhodopseudomonas capsulata. Archives of Microbiology 138, 233-236.

Siegal, R. \& RYU, D. D. Y. (1985). Kinetic study of instability of recombinant plasmid pPLc23trpAI in $E$. coli using a two stage continuous culture system. Biotechnology and Bioengineering 27, 28-33.

SISTROM, W. R. (1977). Transfer of chromosomal genes mediated by plasmid R68.45 in Rhodopseudomonas sphaeroides. Journal of Bacteriology 131, $526-532$.

Sistrom, W. R., Macaluso, A. \& Pledger, R. (1984). Mutants of Rhodopseudomonas sphaeroides useful in genetic analysis. Archives of Microbiology 138 161-165.

Stankowski, L. R., JR, Taindall, K. R. \& Hsie, A. W. (1986). Quantitative and molecular analysis of ethyl methanesulfonate and ICR 191-Induced mutations in AS52 cells. Mutation Research 160, 133-147.

TABITA, F. R. (1981). Molecular regulation of carbon dioxide assimilation in autotrophic organisms. In Microbial Growth on $C_{1}$ Compounds, pp. 70-81. Edited by H. Dalton. London: Heydon \& Sons.

TABITA, F. R. (1988). Molecular and cellular regulation of autotrophic carbon dioxide fixation in microorganisms. Microbiological Reviews 52, 155-189.

Tabita, F. R., Caruso, P. \& Whitman, W. (1978). Facile assay of enzymes unique to the Calvin cycle, with special reference to ribulose 1,5-bisphosphate carboxylase. Analytical Biochemistry 84, 462-472.

Vieira, J. \& MEssing, J. (1982). The pUC plasmids, an M13mp7-derived system for insertion mutagenesis and sequencing with synthetic universal primers. Gene 19, 259-268.

WEAVER, K. E. (1985). Molecular regulation of ribulose 1,5-bisphosphate carboxylase/oxygenase in Rhodo- 
pseudomonas sphaeroides. PhD dissertation, University of Texas at Austin, Austin, Texas.

WEAVER, K. E. \& TABITA, F. R. (1983). Isolation and partial characterization of Rhodopseudomonas sphaeroides mutants defective in the regulation of ribulose biphosphate carboxylase/oxygenase. Journal of Bacteriology 156, 507-515.

Weaver, K. E. \& TABITA, F. R. (1985). Complementation of a Rhodopseudomonas sphaeroides ribulose bisphosphate carboxylase-oxygenase regulatory mutant from a genomic library. Journal of Bacterio$\log y 164,147-154$

Whitman, W. \& TABita, F. R. (1976). Inhibition of ribulose 1,5-bisphosphate carboxylase by pyridoxal 5-phosphate. Biochemical and Biophysical Research Communications 71, 1034-1039.
Willison, J. C. \& Vignais, P. M. (1982). The use of metronidazole to isolate $\mathrm{Nif}^{-}$mutants of Rhodopseudomonas capsulata and the identification of a mutant with altered regulatory properties of nitrogenase. Journal of General Microbiology $\mathbf{1 2 8}$, 3001-3010.

Willison, J. C., Magnin, J. P. \& Vignais, P. M. (1987). Isolation and characterization of Rhodobacter capsulatus strains lacking endogenous plasmids. Archives of Microbiology 147, 134-142.

Yanish-Perron, C., Vieira, J., Messing, J. (1985). Improved M13 phage cloning vectors and host strains: nucleotide sequences of the M13mp18 and pUC19 vectors. Gene 33, 103-119. 